\title{
Małgorzata Blażejowska
}

Politechnika Koszalińska

e-mail: blazejowska@op.pl

\section{SPÓŁDZIELCZOŚĆ SOCJALNA \\ NA OBSZARACH WIEJSKICH NA PRZYKŁADZIE WOJEWÓDZTWA MALOPOLSKIEGO}

\section{SOCIAL COOPERATION \\ ON RURAL AREAS BASED ON THE EXAMPLE OF THE MALOPOLSKA VOIVODESHIP}

DOI: $10.15611 / \mathrm{pn} .2019 .544 .01$

JEL Classification: D69

Streszczenie: Celem artykułu jest przedstawienie funkcjonowania spółdzielczości socjalnej na obszarach wiejskich na przykładzie 14 spółdzielni socjalnych działających w gminach wiejskich województwa małopolskiego co najmniej od czterech lat. $\mathrm{Na}$ podstawie danych z KRS zbadano profil działalności, poziom zatrudnienia, okres prowadzenia działalności, podmioty założycielskie oraz sytuację finansową analizowanych jednostek przy wykorzystaniu metody indeksów dynamiki. Wyodrębniono spółdzielnie pod względem podmiotowości prawnej założycieli celem wskazania różnic. Wśród spółdzielni założonych przez osoby prawne w większości z nich $(63 \%)$ nastąpił wzrost przychodów w porównaniu z rokiem ubiegłym. Spośród podmiotów założonych przez osoby fizyczne $50 \%$ badanych odnotowała bardzo niskie przychody, co było powodem zaprzestania prowadzenia działalności. Wyniki badań wykazały, że największe szanse na rozwój mają spółdzielnie założone przez osoby prawne i świadczące usługi na rzecz organów samorządowych.

Słowa kluczowe: spółdzielnie socjalne, obszary wiejskie, województwo małopolskie.

Summary: The article anlyzes 14 social cooperatives operating in rural areas of the Małopolska Voivodeship for at least 4 years. Based on the data from the National Court Register, the profile of activity, number of employees, period of activity, founders and financial situation were analyzed using the dynamics index method. The differences in the functioning of social cooperatives, due to the legal status of the founders, were indicated. Among the cooperatives founded by legal persons most of them (63\%) saw an increase in revenues in comparison to the previous year. Among the cooperatives founded by physical persons $50 \%$ of them recorded very low revenues and ceased to conduct their operations. The results of the research show that cooperatives founded by legal persons have the greatest chance of development.

Keywords: social cooperatives, rural areas, Małopolska Voivodeship. 


\section{Wstęp}

Spółdzielnie socjalne stanowią jedną z form prawnych podmiotów ekonomii społecznej. Zgodnie z treścią ustawy o spółdzielniach socjalnych, poza prowadzeniem działalności gospodarczej opartej na osobistej pracy członków organizacja działa na rzecz społecznej oraz zawodowej reintegracji osób wykluczonych bądź zagrożonych wykluczeniem społecznym. Przedmiotem działalności spółdzielni może być również prowadzenie działalności społecznej i oświatowo-kulturalnej na rzecz swoich członków, pracowników oraz środowiska lokalnego, a także działalność społecznie użyteczna w sferze działań publicznych. Początkowo założycielami takich przedsiębiorstw mogły być tylko osoby fizyczne. Wprowadzenie do ustawy możliwości zakładania spółdzielni socjalnych przez osoby prawne wiązało się z narastającym od kilku lat przekonaniem, że dla osób społecznie marginalizowanych to zadanie może być zbyt trudnym wyzwaniem. Trudno oczekiwać, żeby osoby obarczone licznymi problemami (długotrwałe bezrobocie, bezdomność, uzależnienia, pobyt w zakładach karnych, niepełnosprawność) nie tylko pokonały te problemy, ale też stały się przedsiębiorcami z sukcesem prowadzącymi własną spółdzielnię. Kierując się tym sposobem myślenia, w nowelizacji ustawy z 2009 roku, poza wprowadzeniem możliwości zakładania spółdzielni socjalnych przez osoby prawne, zmniejszono również proporcję pomiędzy osobami zagrożonymi wykluczeniem społecznym a pozostałymi członkami z $80 \%$ do 50\% [Węsierska-Chyc 2015, s. 57]. Zgodnie z nowelizacją ustawy z 2018 roku spółdzielnię mogą założyć co najmniej trzy osoby fizyczne lub dwie enumeratywnie wyszczególnione osoby prawne, takie jak: jednostki samorządowe, organizacje pozarządowe i kościelne osoby prawne. W wielu krajach europejskich w ostatnich kilku dekadach przedsiębiorstwa społeczne rozwijały się niezwykle dynamicznie, szybciej niż pozostałe gałęzie gospodarki [Borzaga, Salvatori, Bodini 2017, s. 4]. Również w Polsce zainteresowanie zakładaniem spółdzielni socjalnych w gminach wiejskich jest coraz większe (por. [Suchoń 2013; Błażejowska 2011; Łącka 2017]). O sukcesie przedsiębiorstwa społecznego decyduje ekonomiczna aktywność członków oraz osiąganie zysku, który służy realizacji celu nadrzędnego, jakim jest zapewnienie pracy osobom tworzącym spółdzielnię. Główną charakterystyką tych podmiotów jest to, że nie działają dla zysku własnego, lecz członków [Suchoń 2013, s. 2]. Dodatkowe korzyści z funkcjonowania przedsiębiorstw społecznych w lokalnym środowisku czerpie także społeczność na danym terytorium ze względu na profil aktywności tego typu podmiotów. Zgodnie z ideą ekonomii społecznej, zawsze realizują one cele społeczne w sferach, które są zaniedbane przez sektor publiczny i rynek [Łącka 2017, s. 57]. Kluczowe znaczenie w funkcjonowaniu spółdzielni socjalnych mają lokalne władze samorządowe, które mogą być animatorami powstania przedsiębiorstw społecznych, zleceniodawcami oraz podmiotami oferującymi wsparcie w postaci na przykład użyczenia lokali lub gruntów oraz zamieszczania materiałów promocyjnych i reklamowych na urzędowych stronach internetowych [Błażejowska 2011, s. 35]. 


\section{Cel, materiał i metodyka badań}

Celem artykułu jest przedstawienie funkcjonowania spółdzielczości socjalnej na obszarach wiejskich na przykładzie 14 spółdzielni socjalnych działających na terenie woj. małopolskiego. Za obszary wiejskie uznano gminy wiejskie i miejsko-wiejskie. Szczegółowe dane dotyczące założycieli, profilu działalności, roku powstania, liczby zatrudnionych pracowników oraz sytuacji finansowej poszczególnych podmiotów uzyskano z Krajowego Rejestru Sądowego (KRS). Dokumentami umożliwiającymi określenie sytuacji ekonomicznej spółdzielni były aktualne sprawozdania finansowe, bilanse, rachunki zysków i strat oraz sprawozdania z prowadzonej działalności. Przy wyborze spółdzielni do badań kierowano się faktem złożenia sprawozdania finansowego oraz funkcjonowania na rynku co najmniej od 2014 roku. Według Ogólnopolskiego Katalogu Spółdzielni Socjalnych [Ogólnopolski...] w woj. małopolskim są zarejestrowane 103 spółdzielnie socjalne (stan na dzień 31.12.2018). Faktycznie aktywnych spółdzielni jest znacznie mniej, co stwierdzono podczas zbierania danych do niniejszego artykułu. Wiele spółdzielni zostało już zlikwidowanych albo nie prowadzi działalności. Powstały one w wyniku unijnego wsparcia finansowego i po zakończeniu dofinansowania zaprzestały działalności. Jednakże kosztowny proces lustracji powoduje, że w dalszym ciągu figurują one w KRS, przez co wprowadzają w błąd co do faktycznej liczby przedsiębiorstw istniejących. Należy również uwzględnić fakt, że większość spółdzielni działa w gminach miejskich. Mała liczba podmiotów funkcjonujących na obszarach wiejskich województwa małopolskiego jest efektem braku aktywności władz samorządowych. Jak wynika z badań [Dziadkowiec 2017, s. 14], na terenie województwa małopolskiego głównie gminy wiejskie nie postrzegają ekonomii społecznej jako sposobu na rozwiązywanie lokalnych problemów w strategiach rozwoju lokalnego. Prawie w jednej trzeciej gmin miejsko-wiejskich i tylko w 5\% gmin wiejskich stosowano różnorodne formy wsparcia podmiotów ekonomii społecznej. W wyniku dokonanej selekcji zebrano dane dotyczące 6 spółdzielni założonych przez osoby fizyczne i 8 założonych przez osoby prawne. Wyodrębniono spółdzielnie pod względem podmiotowości prawnej założycieli celem wskazania różnic. Zebrane dane analizowano również przy użyciu indeksów dynamiki (rok poprzedni $=100$ ), uwzględniając przychody uzyskane w 2015 i 2016 roku. Wartości finansowe zostały zaokrąglone do pełnych złotych.

\section{Wyniki badań}

W związku z tym, że badane spółdzielnie prowadzą przede wszystkim usługi, wysokość przychodu odzwierciedla sytuację finansową, pozwalającą określić aktywność przedsiębiorstwa, a zarazem stanowi punkt odniesienia przy ocenie wielkości zysku i zaangażowania zasobów. Warto zaznaczyć, że wszyscy członkowie są jednocześnie pracownikami na podstawie spółdzielczej umowy o pracę, a w związku z tym wypłacane są im comiesięczne wynagrodzenia, które stanowią koszt prowadzonej 
działalności. Jak wynika z tabeli 1, wśród spółdzielni założonych przez osoby fizyczne tylko dwie w ubiegłym roku osiągnęły zysk z prowadzonej działalności. Największy sukces odniosła spółdzielnia „Fightman” z Brzeska, która odnotowała dochód w wysokości 13,04 tys. zł i której przychody wzrosły o 91\% w porównaniu z rokiem ubiegłym. Organizacja zajmuje się prowadzeniem siłowni.

Tabela 1. Spółdzielnie socjalne założone przez osoby fizyczne na obszarach wiejskich województwa małopolskiego

\begin{tabular}{|l|c|c|c|c|c|c|}
\hline $\begin{array}{l}\text { Nazwa, obszar i główny } \\
\text { profil działania }\end{array}$ & $\begin{array}{c}\text { Rok } \\
\text { założenia }\end{array}$ & $\begin{array}{c}\text { Przychody } \\
\text { w 2015 } \\
\text { (tys. zł) }\end{array}$ & $\begin{array}{c}\text { Przychody } \\
\text { w 2016 } \\
\text { (tys. zł) }\end{array}$ & $\begin{array}{c}\text { Dynamika } \\
\text { przychodów } \\
\text { (2015=100) }\end{array}$ & $\begin{array}{c}\text { Zysk } \\
\text { (strata) } \\
\text { w 2016 } \\
\text { (tys. zł) }\end{array}$ & $\begin{array}{c}\text { Liczba osób } \\
\text { zatrudnionych }\end{array}$ \\
\hline $\begin{array}{l}\text { „Serce Pogórza”, } \\
\text { Dzierżaniny, } \\
\text { gastronomia }\end{array}$ & 2011 & 401,07 & 407,18 & 101,5 & $-12,63$ & 8 \\
\hline $\begin{array}{l}\text { „Kuźnia Smaku”, } \\
\text { Czasław, gastronomia }\end{array}$ & 2013 & 641,64 & 775,16 & 120,8 & 0,37 & 5 \\
\hline $\begin{array}{l}\text { „Fightman”, Brzesko, } \\
\text { siłownia }\end{array}$ & 2013 & 132,17 & 251,95 & 190,6 & 13,04 & 8 \\
\hline $\begin{array}{l}\text { „Husaria”, Bolęcin, } \\
\text { usługi porządkowe } \\
\text { i tereny zielone }\end{array}$ & 2014 & 46,03 & 2,26 & 4,9 & $-11,9$ & 6 \\
\hline $\begin{array}{l}\text { Spółdzielnia im. } \\
\text { J. Korczaka, Zgłobice, } \\
\text { usługi opiekuńcze }\end{array}$ & 2014 & 73,85 & 42,22 & 57,2 & $-28,1$ & 5 \\
\hline $\begin{array}{l}\text { „Emu”, Mogilno, usługi } \\
\text { porządkowe }\end{array}$ & 2014 & 100,97 & 19,92 & 19,7 & $-4,55$ & 9 \\
\hline
\end{tabular}

Źródło: opracowanie własne na podstawie danych z KRS.

Spółdzielnia socjalna „Kuźnia Smaku” również osiągnęła w 2016 roku dochód w kwocie 377 zł. Poza działalnością gastronomiczną przedsiębiorstwo od 2013 roku w ramach konkursu ogłoszonego przez Urząd Gminy Raciechowice realizuje zadanie publiczne pod nazwą ,Wspieranie osób w podeszłym wieku w integracji z młodzieżą”. Mimo że spółdzielnia „Serce Pogórza” nie uzyskała w 2016 roku dochodu, podmiot ma ustabilizowane przychody od 2011 roku średnio na poziomie 400 tys. zł, gdyż zleceniodawcą jest GOPS w Zakliczynie, placówki oświatowe oraz Europejskie Centrum Muzyki w Lusławicach. Pozostałe trzy badane podmioty zaprzestały prowadzenia działalności, o czym świadczy brak kontaktu z nimi oraz fakt niezłożenia wymaganych przez KRS dokumentów finansowych za 2017 rok. Spółdzielnia „Emu” rozpoczęła działalność w 2014 roku. W tym roku otrzymała na rozpoczęcie działalności wsparcie inwestycyjne ze środków publicznych w wysokości 78,87 tys. zł oraz wsparcie tzw. pomostowe w wysokości 19,2 tys. zł. Faktycznie dopiero w 2015 roku spółdzielnia samodzielnie zaczęła uzyskiwać przychody, świadcząc usługi porządkowe. Niestety, z powodu braku zleceń w 2016 roku uzyskała przy- 
chód w wysokości 19,92 tys. zł. Analogiczna sytuacja jest w spółdzielni socjalnej „Husaria”, która wykonując usługi gastronomiczne i porządkowe, w 2016 roku bez wsparcia osiągnęła bardzo niskie przychody w kwocie 2,26 tys. zł. Statutowa działalność odpłatna Spółdzielni im. Janusza Korczaka polegała na świadczeniu zleconych usług opiekuńczych w domach podopiecznych oraz usług porządkowych. W ramach statutowej działalności nieodpłatnej spółdzielnia realizowała zadanie publiczne gminy Tarnów pod nazwą: „Prowadzenie działalności rehabilitacyjnej i terapeutycznej dla osób niepełnosprawnych". Organizacja prowadziła cykliczne zajęcia w ramach fizykoterapii i terapii zajęciowej. Dużą wagę przykładano do podtrzymywania więzi międzypokoleniowej poprzez organizację zajęć uczestników i młodych członków ich rodzin (np. dzieci i wnucząt) w formie regularnych (raz w tygodniu) spotkań i nauki uczestników podstawowej obsługi komputera i Internetu. O celowości i wartości projektu świadczy fakt, że wszyscy uczestnicy wyrazili bardzo pozytywne oceny i sugestie, by tego typu działania były prowadzone również w kolejnych latach. Spółdzielnia zamknęła rok obrotowy nadwyżką kosztów nad przychodami w wysokości 28,9 tys. zł, co było głównym powodem zawieszenia działalności od 2017 roku. Brak zapewnienia odpowiedniego poziomu przychodów z działalności gospodarczej prowadzonej przez przedsiębiorstwa społeczne (spółdzielnie socjalne) stanowi obecnie w Polsce bardzo poważny problem, co często prowadzi do bankructwa tego typu podmiotów ekonomii społecznej [Tworek, Cziura 2017, s. 96].

Spośród spółdzielni założonych przez osoby prawne na szczególne uznanie zasługuje spółdzielnia „Opoka” powstała w 2009 roku z inicjatywy dwóch organizacji pozarząadowych - Chrześcijańskiego Stowarzyszenia Dobroczynnego w Kluczach oraz Stowarzyszenia na rzecz Zrównoważonego Rozwoju Społeczno-Gospodarczego „Klucz” z Kolbarka. Spółdzielnia zatrudnia 62 osoby, w tym 32 z niepełnosprawnościami. 2016 był ostatnim rokiem, w którym jednostka wykazywała stratę z prowadzonej działalności, gdyż w 2017 roku spółdzielnia uzyskała dochód w wysokości 358,88 tys. zł. Jak wynika z tabeli 2, najwyższy dochód w 2016 roku, w kwocie 194,98 tys. zł, uzyskała spółdzielnia „Czystość” z Sękowej. Organizacja po drugim roku działalności odnalazła swoje miejsce na lokalnym rynku, gdzie rozpoznawana jest jako realizator, partner i podwykonawca w różnych przedsięwzięciach z zakresu budowy i remontu dróg i placów użyteczności publicznej oraz utrzymania zieleni. Spółdzielnia sukcesywnie powiększa swój park maszynowy od drobnych urządzeń i elektronarzędzi po specjalistyczne maszyny. Dużą wagę przywiązuje do doskonalenia kapitału ludzkiego, kierując pracowników na dodatkowe szkolenia pozwalające na nabywanie nowych uprawnień. W 2016 roku koszty spółdzielni pokrywane były przede wszystkim z uzyskanych przychodów z tytułu świadczonych usług, które wyniosły $1,15 \mathrm{mln}$ zł. Wykorzystano również instrumenty wsparcia przewidziane dla podmiotów ekonomii społecznej. Z PUP w Gorlicach pozyskano 49,14 tys. zł w formie refundacji części wynagrodzeń pracowników zatrudnionych w spółdzielni oraz składek ZUS. Z kolei gmina Sękowa udzieliła spółdzielni dotacji celowej w wysokości 36 tys. zł z przeznaczeniem na dofinansowanie zakupu 
koparki. Pozostałą część inwestycji sfinansowano ze środków własnych spółdzielni (tj. 84 tys. zł). W okresie objętym sprawozdaniem zakupiono też inne środki trwałe o wartości 26,67 tys. zł. Nawiązywanie nowych kontaktów handlowych, inwestowanie w niezbędny sprzęt i wzmacnianie kapitału ludzkiego służy umocnieniu pozycji spółdzielni na rynku.

Tabela 2. Spółdzielnie socjalne założone przez osoby prawne na obszarach wiejskich województwa małopolskiego

\begin{tabular}{|c|c|c|c|c|c|c|}
\hline $\begin{array}{l}\text { Nazwa, obszar } \\
\text { działania, rok } \\
\text { założenia i główny } \\
\text { profil działania }\end{array}$ & Założyciele & $\begin{array}{l}\text { Przychody } \\
\text { w } 2015 \\
\text { (tys. zł) }\end{array}$ & $\begin{array}{l}\text { Przychody } \\
\text { w } 2016 \\
\text { (tys. zł) }\end{array}$ & $\begin{array}{c}\text { Dynamika } \\
\text { przychodów } \\
(2015=100)\end{array}$ & 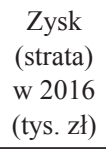 & $\begin{array}{l}\text { Liczba osób } \\
\text { zatrudnionych }\end{array}$ \\
\hline $\begin{array}{l}\text { „Grosik”, Jordanów, } \\
\text { 2012, usługi } \\
\text { porządkowe } \\
\text { i budowlane }\end{array}$ & $\begin{array}{l}\text { gmina Jordanów } \\
\text { i Stowarzyszenie } \\
\text { Trzeźwości } \\
\text { „Dom” }\end{array}$ & 304,02 & 310,12 & 102 & 1,94 & 7 \\
\hline $\begin{array}{l}\text { „Przystań”, } \\
\text { Raciechowice, 2011, } \\
\text { gastronomia i usługi } \\
\text { porządkowe }\end{array}$ & $\begin{array}{l}\text { gmina } \\
\text { Raciechowice } \\
\text { i OSP }\end{array}$ & 965,15 & 872,02 & 90,3 & $-9,69$ & 20 \\
\hline $\begin{array}{l}\text { „Krok do Przodu”, } \\
\text { Brzezie, 2013, } \\
\text { usługi porządkowe } \\
\text { i remontowe }\end{array}$ & $\begin{array}{l}\text { gmina Kłaj } \\
\text { i Stowarzyszenie } \\
\text { „Dobro Dziecka” }\end{array}$ & 183,42 & 119,14 & 64,9 & $-1,97$ & 5 \\
\hline $\begin{array}{l}\text { „Podkówka”, } \\
\text { Sułkowice, 2014, } \\
\text { gastronomia }\end{array}$ & $\begin{array}{l}\text { gmina } \\
\text { Sułkowice i OSP } \\
\text { w Sułkowicach } \\
\end{array}$ & 323,64 & 361,23 & 111,6 & $-20,03$ & 5 \\
\hline $\begin{array}{l}\text { „Czystość”, Sękowa, } \\
\text { 2014, usługi } \\
\text { remontowo- } \\
\text {-budowlane }\end{array}$ & \begin{tabular}{|l|} 
gmina \\
Sękowa oraz \\
Stowarzyszenie \\
Promocji \\
i Rozwoju \\
\end{tabular} & 849,1 & 1235,98 & 130,2 & 194,98 & 10 \\
\hline $\begin{array}{l}\text { „Okno na Świat”, } \\
\text { Słopnice, 2014, } \\
\text { usługi opiekuńcze }\end{array}$ & $\begin{array}{l}\text { gmina Słopnice } \\
\text { i Fundacja KTO }\end{array}$ & 157,48 & 197,59 & 125,5 & $-26,38$ & 14 \\
\hline $\begin{array}{l}\text { „Opoka”, Klucze, } \\
\text { 2009, gastronomia }\end{array}$ & $\begin{array}{l}\text { dwie organizacje } \\
\text { pozarządowe }\end{array}$ & 1328,34 & 2131,30 & 160,4 & $-17,5$ & 62 \\
\hline $\begin{array}{l}\text { „Prima”, Pcim, } \\
\text { 2012, gastronomia }\end{array}$ & $\begin{array}{l}\text { gmina Pcim } \\
\text { i Koło Gospodyń } \\
\text { Wiejskich }\end{array}$ & 648,91 & 624,24 & 96,2 & $-77,79$ & 15 \\
\hline
\end{tabular}

Źródło: opracowanie własne na podstawie danych z KRS.

Dochód z prowadzonej działalności gospodarczej osiągnęła również spółdzielnia socjalna „Grosik”, która wykonuje usługi porządkowe i remontowo-budowlane. Organizacja pozyskała zlecenia od gminnych i powiatowych władz samorządowych - aż 74\% dochodu stanowią zlecenia z Urzędu Miasta dotyczące utrzymania czystości i zieleni miejskiej. Współpraca z Sądem Rejonowym w Suchej Beskidzkiej 
dała efekty w postaci skierowania do pracy w spółdzielni osób skazanych na karę ograniczenia wolności. W 2014 roku na cele społeczne wykonywano prace nieodpłatne i dozorowane w wymiarze 500 godzin, a w 2015 roku w wymiarze 100 godzin. Spółdzielnia posiada środki trwałe o wartości 148,65 tys. zł, m.in. koparkę za 80 tys. zł oraz samochód ciężarowy za 35 tys. zł. Sytuacja finansowa pozostałych podmiotów założonych przez osoby prawne (poza jedną spółdzielnią) również jest stabilna, mimo że nie uzyskały one w 2016 roku dochodu. W większości z nich (63\%) nastąpił wzrost przychodów w porównaniu z rokiem ubiegłym. Spółdzielniom nie grozi utrata płynności finansowej w dużej mierze dzięki postawie założycieli, którzy są jednocześnie zleceniodawcami. Spółdzielnia socjalna „Okno na Świat" wykonuje usługi opiekuńcze zarówno nad dziećmi do lat 3, jak i osobami starszymi. W 2016 roku w spółdzielni pracowało 14 osób, w tym na umowę o pracę 9 , na umowę zlecenie 4 i na umowę o dzieło 2. Jednostka korzystała z resortowego ministerialnego programu rozwoju instytucji opieki nad dziećmi w wieku do lat 3 MALUCH. Spółdzielnia realizowała również usługi opiekuńcze na zlecenie GOPS w Słopnicach i w Tymbarku. W ramach działalności społecznej jednostka brała udział w organizacji Gminnego Dnia Dziecka w Słopnicach, z Fundacją KTO Kultura -Troska - Otwartość zorganizowała transport pomocy żywnościowej z Banku Żywności w Krakowie oraz zajęła się dystrybucją żywności dla rodzin najuboższych na terenie gminy. Ponadto pracownice spółdzielni przez 6 miesięcy wolontaryjnie realizowały zajęcia dla dzieci w ramach programu „Wczesne wspomaganie rozwoju dzieci z terenu gminy Słopnice”. Spółdzielnia socjalna „Przystań” powstała z inicjatywy gminy Raciechowice oraz organizacji pozarządowej, tj. OSP w Kwapince. Jednostka od siedmiu lat świadczy usługi gastronomiczne dla trzech szkół oraz klientów GOPS-u, wydając dziennie ponad 400 obiadów, oraz usługi cateringowe podczas szkoleń i konferencji. Drugim zadaniem realizowanym przez organizację są usługi porządkowe w obiektach szkolnych oraz w Urzędzie Gminy Raciechowice. Podmiot zarządza również pensjonatem Kwapinka. W 2016 roku spółdzielnia zatrudniała 20 osób. Organizacja posiada środki trwałe o wartości 231,76 tys. zł i ustabilizowane przychody na poziomie ok. 900 tys. rocznie. Z inicjatywy władz samorządowych gminy oraz OSP w Sułkowicach powstała spółdzielnia socjalna „Podkówka”. Głównym profilem działalności jest prowadzenie restauracji w Sułkowicach, będącej jednocześnie miejscem spotkań dla okolicznych mieszkańców i licznych organizacji, z którymi współpracuje. Przedsiębiorstwo stale się rozwija. Jak wynika ze sprawozdania z działalności, w 2017 roku spółdzielnia rozszerzyła asortyment, dzięki czemu wzrosła liczba klientów i przez co dwukrotnie zwiększyły się przychody jednostki. Stabilną sytuację finansową ma również spółdzielnia „Prima”. Obsługując od 2012 stołówki szkolne i przedszkolne na terenie gminy Pcim, organizując imprezy oraz sprzedając własne wyroby garmażeryjne, osiąga przychody na porównywalnym poziomie, tzn. ok 600 tys. zł rocznie. Dzięki inicjatywie gminy i koła gospodyń wiejskich zatrudnienie w spółdzielni znalazło 15 kobiet, głównie byłych pracownic stołówek. Organizacja działała na rzecz lokalnej społeczności, prowadząc warsztaty 
z edukacji żywieniowej zarówno dla młodzieży, jak i dorosłych. Na skutek zakupu środków trwałych spółdzielnia w 2016 roku poniosła stratę na prowadzonej działalności w wysokości 77,79 tys. zł, która w 2017 roku została zmniejszona do 21,35 tys. zł. Spośród 8 spółdzielni założonych przez osoby prawne tylko jedna z nich zawiesiła w 2017 roku prowadzenie działalności gospodarczej - jest to spółdzielnia „Krok do Przodu”, powstała dzięki inicjatywie gminy Kłaj i Stowarzyszenia Rodziców Dzieci Niepełnosprawnych „Dobro Dziecka”, które prowadzi Środowiskowy Dom Samopomocy w Brzeziu. Sprzyjającą okolicznością do założenia spółdzielni była możliwość przystąpienia do projektu zarządzanego przez Małopolski Instytut Samorządu Terytorialnego i Administracji w Krakowie, a współfinansowanego ze środków Europejskiego Funduszu Społecznego. W 2015 roku zakończył się okres projektowy, a tym samym możliwość finansowania niektórych kosztów funkcjonowania spółdzielni (tzw. środki pomostowe - przeznaczone np. na ubezpieczenia społeczne, media itp.), dlatego też w 2016 roku nastąpił zauważalny spadek przychodów w porównaniu z rokiem ubiegłym. W 2017 roku spółdzielnia zaprzestała prowadzenia działalności, mimo zaangażowania ze strony władz samorządowych w postaci użyczenia lokalu użytkowego na prowadzenie sklepu z artykułami używanymi, zlecenia usług w postaci obsługi Punktu Selektywnej Zbiórki Odpadów Komunalnych oraz realizacji umowy o stałej współpracy z Zespołem Szkół w Kłaju, związanej z pilnowaniem i monitoringiem kompleksu sportowego. Jako przyczynę zaprzestania prowadzenia działalności podano brak lidera w spółdzielni oraz pomysłów, jak pozyskać i zatrzymać pracowników.

\section{Zakończenie}

Na podstawie przeprowadzonych badań wykazano różnice w funkcjonowaniu spółdzielni socjalnych na obszarach wiejskich województwa małopolskiego. Wynikają one z podmiotowości prawnej założycieli. Wśród podmiotów założonych przez osoby prawne w większości z nich $(63 \%)$ nastąpił wzrost przychodów w porównaniu $\mathrm{z}$ rokiem ubiegłym. Sytuacja finansowa $88 \%$ badanych jednostek jest stabilna i nie grozi im niewypłacalność. Mimo że nie osiągnęły dochodu, posiadają liczne środki trwałe, stałe zlecenia i zatrudniają średnio 19 osób. Spośród podmiotów założonych przez osoby fizyczne, zatrudniających średnio 7 osób, 50\% badanych uzyskało bardzo niskie przychody i w efekcie zaprzestała prowadzenia działalności. Dominującym profilem działalności podmiotów funkcjonujących na obszarach wiejskich były usługi gastronomiczne (43\%), porządkowe (29\%) oraz remontowo-budowlane (21\%). Na podstawie powyższej analizy można stwierdzić, że znaczący wpływ na rozwój społeczno-gospodarczy obszarów wiejskich mogą mieć przede wszystkim przedsiębiorstwa społeczne zakładane przez osoby prawne i świadczące usługi użyteczności społecznej na rzecz organów samorządowych. 


\section{Literatura}

Błażejowska M., 2011, Funkcjonowanie podmiotów ekonomii społecznej na obszarach wiejskich na przykładzie spółdzielni socjalnych, Zeszyty Naukowe SGGW w Warszawie, Problemy Rolnictwa Światowego, t. 11 (26), z. 4, s. 26-36.

Borzaga C., Salvatori G., Bodini R., 2017, Social and Solidarity Economy and the Future of Work, International Labour Office, Geneva.

Dziadkowiec A., 2017, Monitoring kondycji sektora ekonomii społecznej w Małopolsce. Skrócony raport z badań za 2016 r. Wybrane zagadnienia, ROPS, Kraków.

Łącka I., 2017, Przedsiębiorczość społeczna a wykluczenie społeczne na obszarach wiejskich w Polsce, Zeszyty Naukowe WSES w Ostrołęce, nr 4, s. 41-60.

Ogólnopolski Katalog Spółdzielni Socjalnych, www.spoldzielniesocjalne.org.

Suchon A., 2013, The principles of the organization and operations of social cooperatives for rural development the light of the legal regulations in Poland, Journal of Agribusiness and Rural Development, 3 (29), s. 179-192.

Tworek P., Cziura P., 2017, Wybrane problemy zarządzania ryzykiem w działalności przedsiębiorstw społecznych, Zeszyty Naukowe Politechniki Częstochowskiej, Zarządzanie, nr 25, t. 1, s. 95-108.

Ustawa z 27.04. 2006 r. o spółdzielniach socjalnych, Dz.U. z 2006 r., nr 94, poz. 651 z późn. zm.

Węsierska-Chyc L., 2015, Czy spółdzielnia socjalna osób prawnych jest przedsiębiorstwem społecznym? [w:] Janocha W., Koperek J., Zielińska-Król K. (red.), Spółdzielnie socjalne jako instrument polityki społecznej państwa, KUL, Lublin. 